\title{
BELIEFS OF POETS REGARDING THE TRIGGERS OF SUICIDE
}

\author{
SAXBY PRIDMORE \\ s.pridmore@utas.edu.au \\ School of Medicine, \\ University of Tasmania, Hobart, Tasmania; \\ Saint Helen's Hospital, Hobart \\ (corresponding author) \\ JAMSHID AHMADI \\ Substance Abuse Research Centre, \\ Shiraz University of Medical Sciences, Shiraz \\ WILLIAM PRIDMORE \\ Australian National University Medical School, Canberra
}

\begin{abstract}
Background. Over the last century, the claim has been made that suicide is always, or almost always, the result of mental disorder. Aim. To explore the beliefs of famous English speaking poets regarding the triggers of suicide. Method. Poetry libraries were explored for poetry giving information regarding the attitude of writers to the triggers of suicide. This material was analysed and categorized. Results. Fifteen poems (separate poets) were identified and examined. The triggers of suicide included mental disorder and socioeconomic stressors (acute and chronic). In a minority of cases (four), categorization could not be made. Conclusions. Poets describe the triggers of suicide as including not only mental disorder, but also socioeconomic (acute and chronic) factors.
\end{abstract}

Keywords: suicide; suicide prevention; mental disorder

How to cite: Pridmore, Saxby, Jamshid Ahmadi, and William Pridmore (2017), "Beliefs of

Poets Regarding the Triggers of Suicide," American Journal of Medical Research 4(2): 7-19.

Received 9 November $2016 \cdot$ Received in revised form 15 December 2016

Accepted 16 December 2016 • Available online 28 December 2016

\section{Introduction}

Over the last century, in the English-speaking world, the "belief" has been repeatedly stated, that suicide is always (Dorpat and Ripley, 1960) or almost always (Insel, 2013) the result of mental disorder. It has been proposed that 
this position has been "proven" using the "psychological autopsy." However, the psychological autopsy is a retrospective method which has recently been discredited (Hjelmeland et al., 2012), and thus the central role of mental disorder in all cases of suicide is in serious doubt.

The effect of the claim that mental disorder is the sole trigger of suicide has been that suicide has become the province of the mental health professions, and experts in other fields (sociology, ethics, philosophy, history, and economics) have been excluded from policy making and the practical management of this behaviour. The scene is set for mental health practitioners to fail, as they have very little ability to impact the economic, social and cultural environments (Harrington, Boski, and Gelfand, 2015; Fitzpatrick and Kerridge, 2013; Pridmore, 2015) which strongly influence suicide rates.

Poets distil and record aspects of human nature and experience, and are an important additional body of knowledge. This study aimed to discover the beliefs of poets about the triggers of suicide.

On the basis that suicide is a behaviour, and behaviour is the response of the organism to its situation, suicide has been described as a response to predicaments, or unpleasant situations with limited escape options (Pridmore, 2009). Four predicaments have been described: 1) untreated or unresponsive mental disorder, 2) socioeconomic stressors, 3) a combination of mental disorder and socioeconomic stressors, and 4) unclassifiable (Pridmore and McArthur, 2010).

Socioeconomic stressors may take the form of acute events such as imprisonment and other immediate losses. Such stressors may also have chronic effects, akin to the "world-weary" state of mind which has been defined as "feelings of weariness, boredom, or cynicism as a result of long experience of life" (Merriam-Webster). World-weariness was first described by the ancient Greeks, and is distinct from major mental disorder.

A poem reflects the poet's beliefs, and views which his/her readership can accept as reasonable.

\section{Method}

The authors explored English paper poetry libraries by hand, and also the web (using the words "poems," "poets," "suicide," and "famous" in various combinations).

Poets were not included merely because they died by suicide. Attention was limited to famous poets/poems.

Poems were listed according to year of birth of the author (poet), along with the country of residence the poet and the name of the poem. [The year of birth of the poet was chosen as in many cases, the precise years in which poems are written and published are unknown]. This data was then rearranged 
according to the trigger of suicide, using three main categories, 1) mental disorder, 2) socioeconomic stressors, and 3) uncertain.

\section{Results}

\section{Overview}

Fifteen poems were identified, by different poets. These were listed in Table 1. The earliest born was Robert Burns (1759), and the latest was Lisa Zaran (1969). There were five poems from the USA, three from both the UK and Ireland, two from Australia, and one from both Scotland and Canada.

Two poets described a suicide triggered by mental disorder, eight described a suicide triggered by socioeconomic stressors, and in four cases no conclusion could be reached. Robert Burns preceded the other poets by a century and used the moral/religious concepts of his time. Thus, it was necessary to create an additional "moral weakness" category. The details are listed in Table 2.

Table 1 Poets arranged by year of birth, country of residence and name of examined poem

\begin{tabular}{|l|l|l|l|}
\hline Poet & Birth Year & Residence & Poem \\
\hline Robert Burns & 1759 & Scotland & 478. Epigram on a Suicide \\
\hline A B Patterson & 1864 & Australia & Waltzing Matilda \\
\hline W B Yeates & 1865 & Ireland & An Irish Airman Foresees Death \\
\hline Edward Robinson & 1869 & USA & Richard Cory \\
\hline Robert Service & 1874 & Canada & A Song of Suicide \\
\hline Siegfried Sassoon & 1886 & UK & Suicide in the Trenches \\
\hline Dorothy Parker & 1893 & USA & Rhyme Against Living \\
\hline Robert Graves & 1895 & UK & Call it a Good Marriage \\
\hline Stevie Smith & 1902 & UK & Exeat \\
\hline Louis MacNeice & 1907 & Ireland & The Suicide \\
\hline A D Hope & 1907 & Australia & A Commination \\
\hline Anne Sexton & 1928 & USA & The Doctor of the Heart \\
\hline Sylvia Plath & 1932 & USA & Electra on Azalea Path \\
\hline Paul Durcan & 1944 & Ireland & Thinking About Suicide \\
\hline Lisa Zaran & 1969 & USA & Leaves \\
\hline
\end{tabular}




\begin{tabular}{|l|l|l|}
\hline \multicolumn{3}{|c|}{$\begin{array}{r}\text { Table } \\
\text { regarding the causal/trigger factors of suicide }\end{array}$} \\
\hline Poet & Poem & Category \\
\hline Plath & Electra on A. Path & Mental Disorder \\
\hline Sexton & The Doctor of the H. & Mental Disorder \\
\hline & & \\
\hline Patterson & Waltzing Matilda & Stressors - socioeconomic \\
\hline Service & A Song of Suicide & Stressors - socioeconomic \\
\hline Yeates & An Irish Airman. & Stressors - socioeconomic \\
\hline Durcan & Thinking about S. & Stressors - socioeconomic \\
\hline Zaran & Leaves & Stressors - socioeconomic \\
\hline Sassoon & Suicide in the T. & Stressors - socioeconomic \\
\hline Smith & Exeat & Stressors - socioeconomic \\
\hline Hope & A Commination & Stressors - socioeconomic \\
\hline & & \\
\hline Robinson & Richard Cory & Uncertain \\
\hline Graves & Call it a Good M. & Uncertain \\
\hline MacNeice & The Suicide & Uncertain \\
\hline Parker & Rhyme against L. & Uncertain \\
\hline & & \\
\hline Burns & 478. Epigram on S. & Moral weakness \\
\hline
\end{tabular}

\section{Details}

Robert Burns (1759-1796)

478. Epigram on a Suicide

“EARTH'D up, here lies an imp o' hell,

Planted by Satan's dibble;

Poor silly wretch, he's damned himsel', To save the Lord the trouble."

Burns ( $18^{\text {th }}$ Century) gives as the trigger of suicide, surrender to the urgings of Beelzebub (that is, Satan). He was writing of moral weakness, which was consistent with the orthodox view of his time.

\section{A B "Banjo" Patterson (1864-1941) Waltzing Matilda}

"Up jumped the swagman and sprang into the billabong. (or pond) 'You'll never take me alive!' said he."

These lines are from the last verse. The story is about an itinerant worker, sitting beside a pond. He had stolen a lamb and put it in his food bag. The owner of the property and three policemen arrived and asked the whereabouts 
of the lamb. Rather than face the consequences of stealing, the swagman threw himself into the pond and drowned.

\section{W B Yeates (1865-1939)}

\section{An Irish Airman Foresees His Death}

"Those I guard I do not love."

This was written during the First World War. The poem concerns an Irish pilot fighting for the United Kingdom, at a time when his country was straining to remain independent from the UK. This line suggests the Airman lacks integration and sense of belonging.

"I balanced all, brought all to mind,

The years to come seemed waste of breath,

A waste of breath the years behind

In balance with this life, this death."

These (the last) lines suggest the pilot was no longer finding pleasure in living. While he does not take deliberate action to end his life, he has a strong premonition of his fate, and does not actively resist his death.

\section{Edward Arlington Robinson (1869-1935)}

\section{Richard Cory}

"We people on the pavement looked at him:

He was a gentleman from sole to crown,

Clean favoured, and imperially slim."

"...richer than a king."

These lines describe a fortunate, wealthy man with no apparent problems.

"And Richard Cory, one calm summer night,

Went home and put a bullet through his head."

These are the last lines. Many positives in Cory's life are listed; however, there is no mention of pleasures or relationships. The suicide has no obvious trigger. The author was possibly indicating a lack of relationships can contribute to a lonely, unhappy life. 
Robert William Service (1874-1958)

A Song of Suicide

"Deeming that I were better dead,

'How shall I kill myself?' I said."

These are the first two lines. The intention to suicide is immediately expressed. Service employs a playful style and details sentimental tales (annoying some readers and delighting others).

"Thus as we sought our griefs to smother,

With kisses we consoled each other."

The protagonist's lover had died of tuberculosis, and he was about to drown himself in the Seine. However, a young stranger jumps in ahead of him (her lover had died in battle). He saves her and they fall in love and cancel their destructive plans. Thus unfortunate predicaments (such as lost love) can trigger suicide.

Siegfried Sassoon (1886-1967)

Suicide in the Trenches

"And whistled early with the lark.

In winter trenches, cowed and glum,

With crumps and lice and lack of rum,

He put a bullet through his brain."

These (last) lines indicate that an initially appropriately happy young man was distressed by the hardships of fighting in the trenches in WWI, and shot himself.

Dorothy Parker (1893-1967)

Rhyme against Living

"If wild my breast and sore my pride,

I bask in dreams of suicide;

If cool my heart and high my head,

I think, 'How lucky are the dead!'”

This is a four line poem. The first two lines suggest distress may lead to suicidal thoughts; the second two lines, while satirical, indicate that (for her) a predisposition to suicide remained, even in good times. Parker was famous for viciously humorous poems, about her romantic life and thoughts of 
suicide. It is probable she believed her predisposition and life events triggered her suicidal thoughts. However, this is uncertain.

\section{$\underline{\text { Robert Graves (1895-1985) }}$}

\section{Call It a Good Marriage}

"More drew those two together,

Despite a lack of children,

Than pulled them apart."

The last line of this poem informs that both partners in this marriage died by suicide. The poem hints at an extramarital affair at some stage, and earlier there is another mention of failure to produce offspring. However, the lines presented above indicate there was no satisfactory explanation.

$\underline{\text { Stevie Smith (1902-71) }}$

\section{Exeat}

"Yet a time may come when a poet or any person

Having a long life behind him, pleasure and sorrow, But feeble now and expensive to his country

And on the point of no longer being able to make a decision

May fancy Life comes to him with love and says:

We are friends enough now for me to give you death;

Then he may commit suicide, then

He may go."

These are the last lines. Smith was an independent yet reclusive woman who suffered "depression" (undefined). She once stated she was so consoled by the thought of death, as a release, that she did not need to commit suicide. In the lines above she states that after a long life, in unpalatable circumstances, suicide is appropriate. This poem suggests that even in the presence of a history of mental disorder, suicide may be a response to chronic life stressors.

\section{Louis MacNeice (1907-1963)}

\section{The Suicide}

"This man with the shy smile...."

This poem concerns a colleague of MacNeice who jumped to his death from his office window. The line above suggests a self-conscious person.

"...There are the bills

In his intray, the ash in the ashtray, the grey memoranda stacked 
Against him, the serried ranks of the box-files, the packed Jury of his unanswered correspondence

Nodding under the paperweight in the breeze

From the window by which he left...."

These lines suggest a burden of stressors triggered this suicide. We do not read of any extraordinary stressor, we assume the decedent had dealt with such stressors in the past, and are left with some uncertainty. Did the quantity of work increase? Did the decedent become less capable of work (say, mental disorder)? Was there an extraordinary, unmentioned stressor? The decedent may have become "world weary," but caution suggests the trigger be considered "uncertain."

\section{A D Hope (1907-2000)}

\section{A Commination}

"In this great Sodom of a world, which turns

The treasure of the intellect to dust

And every gift to some perverted use,

What wonder if the human spirit learns

Recourses of despair or of disgust,

Abortion, suicide and self-abuse."

These lines come mid-way through the poem. This poem is often included in collections of religion inspired verse, Hope's father was a Presbyterian minister, and "commination" is an action of divine vengeance. However, this poem does not argue the sinfulness of suicide, but for "damnation" of those who contribute to the state of the world. This is a statement that life circumstances (unpleasant predicament) can trigger suicide.

\section{Anne Sexton (1928-74)}

\section{The Doctor of the Heart}

"You with the goo on the suction cup.

You with your wires and electrodes."

These lines refer to equipment used in electroconvulsive therapy. Sexton spent time in psychiatric hospitals, where she received this treatment.

"I am no longer the suicide

with her raft and paddle.

Herr Doktor! I'll no longer die 
to spite you, you wallowing

seasick grounded man."

These are the closing lines of the poem. "I am no longer the suicide" suggests Sexton had been experiencing suicidal thoughts but these had ceased. It is reasonable to assume that the message she was sending (along with other points) was that she had experienced suicidal thoughts as a consequence of mental disorder, and this had ceased through treatment.

Sylvia Plath (1932-63)

Electra on Azalea Path

The title, "Electra," refers to Plath having diagnosed herself as suffering an Electra complex. "Azalea Path" refers to the site of her father's grave. This poem was written after her first visit to her father's grave, at the age of 26 years.

"The day you died I went into the dirt."

This is the first line; it refers to her father's death, when she was eight years of age.

"My mother said: you died like a man.

How shall I age into that state of mind?

I am the ghost of an infamous suicide,

My own blue razor rusting at my throat."

Plath's suffered psychiatric problems for which she was hospitalized, and she died by suicide. The line, 'How shall I age into that state of mind?' suggest either or both, 1) self-awareness of a mental health problem which may impair maturation, or 2) awareness that she may not age much more as she may suicide. In the next line she foreshadows her own suicide.

"It was my love that did us both to death."

This is the last line. It is suggestive of pathological guilt feelings. In this poem, Plath is stating her father's death caused her to suffer a mental disorder which would result in her own death. Other stressors included many relationship failures, but probably, mental disorder played a significant part in her suicide. 
Paul Durcan (1944-)

Thinking about Suicide

"Estranged from my family...."

"Men are such po-faced bores.

Each one of them an editor-in-chief."

These lines suggest the writer is not snugly integrated into, and feeling gently supported by, his family and the broader society.

"Although I have 60\% depression, I do not have despair."

Durcan states that he wakes in the morning with "60 per cent depression." This is not defined, and thus, should not be taken to indicate a mental disorder. Today, he continues to delight live audiences.

“....I do not want to go on for the sake of going on -

Seeing the same old, tired-out impressionist paintings again and again?"

These lines, supported by those about "po-faced bores" and "editor(s)-inchief" suggest the poet has been chronically annoyed/stressed and is no longer finding pleasure in living. As he does "not have despair" this low mood is most likely a response to circumstances/stressors rather than a pathological condition.

\section{Lisa Zaran (1969-)}

Leaves

"Buried in the muck, the soot of the city, sorrow for an appetite,"

"You, with your thorny rhythms and tragic, midnight melodies."

These lines from the middle of this short poem detail the unpleasant predicament of the protagonist.

"to commit suicide before."

The last line of the poem suggests a suicidal act is imminent. It appears this act will be in response to socioeconomic stressors. 


\section{Discussion}

The limitations of this study include that we cannot be certain that what appears in poems represents the beliefs of the writers. However, while prose lends itself to "fiction," and the term "poetic licence" is often spoken, there is reason to suppose the contents of these poems fairly closely follows the beliefs of the authors.

"Poetic licence" is a term which refers to both spoken and written (prose and poetry) material, indicating a degree of freedom to depart from facts and the conventional rules of language, in order to create a greater impact.

The famous poet, Allen Ginsberg, said, "Poetry is the outlet for people to say in public what is known in private." As the poet is seeking to achieve an "essence," there is need for close self-reflection, and deception is seldom attempted.

Attention was limited to the work of famous poets. Suicide is a common topic of young, beginning poets, as it is an evocative and widely reported behaviour. Famous poets, however, bring wisdom and maturity to the task.

Robert Burns preceded the other poets by nearly a century and described suicide using the religious concepts of his day. His poem tells that suicide may be triggered by moral weakness (surrendering to temptation by Beelzebub, or Satan). He also outlines the consequences of suicide (damnation, or going to Hell). These ideas do not fit with the concepts of the more modern poets, thus, his poem is listed as a curiosity (an insight into the attitude of an earlier time).

A B "Banjo" Patterson was one of the famous bush-poets of early Australia. Waltzing Matilda is a song, rather than a poem, but a song is a poem accompanied by music. Waltzing Matilda has an important place in Australian culture and is referred to as the unofficial national anthem. It is most surprising (and important) that an unofficial national anthem describes an individual responding to a social stressor (potential imprisonment) by a suicide.

A Song of Suicide (Robert Service) deals with the mental state of two young people who have lost their lovers, and both plan to suicide. Along with Waltzing Matilda it illustrates that suicide may be triggered by acute socioeconomic stressors. In contrast, Thinking about Suicide (Paul Durcan), Exeat (Stevie Smith) and A Commination (A D Hope), along with others, indicate a world-weariness arising from chronic socioeconomic stress.

It may be argued that the Airman in An Irish Airman Foresees His Death (W B Yeates) did not commit suicide, because he did not perform the fatal act himself. However, he had a strong premonition and took no action to avoid death. Such passivity with fatal consequences satisfies most definitions of suicide. 
Four poems (Richard Cory (Edward Robinson), Call it a Good Marriage (Robert Graves), The Suicide (Louis MacNeice), and Rhyme against Living (Dorothy Parker)) give hints, but no details of triggers of suicide. This might be explained in various ways, including that poetry may be abstract and meaning might not always be clear. The unexplained provides an aura of mystery and awe which is useful in poetry and other forms of entertainment. However, it should be remembered that even after close examination of Coroners' reports, it may not always be possible to identify trigger of a particular suicide (Ali et al., 2014).

The claim that suicide is always (Dorpat and Ripley, 1960) or almost always (Insel, 2013) the result of mental disorder has had the regrettable effect of discounting any potential contributions from experts outside the mental health field. Very importantly, this claim has caused the masterful contribution of Durkheim (1951) to be ignored, except by scholars in sociology.

This medical domination has been recently challenged recently (Beattie and Devitt, 2015; World Health Organization, 2014), but there is little sign, at the moment, of it being replaced by a broader, more comprehensive view.

Fitzpatrick and Kerridge (2013) have argued that other disciplines including, philosophy, ethics, history, sociology and economics have much to contribute to our understanding of suicide. This paper adds poetry to that list.

This paper is concerned with what poems can tell us about the beliefs of famous English speaking poets regarding the triggers of suicide. It also reflects views which were acceptable by his/her readership. There are accounts of a German novel (The Sorrows of Young Werther, by Goethe, 1774) and a Hungarian song (Gloomy Sunday, by Seress, 1939) inspiring suicides, but we found nothing of this kind with any English poem.

Mental health professionals should not have total responsibility for suicide prevention, as working alone, they must fail. By adding poets to those have something to contribute to the solution, we are moving one step closer to involving the whole community, which is the only path to the optimal outcome.

Conflict of interests: nil.

Acknowledgements: nil.

\section{REFERENCES}

Ali, N., K. Zainun, N. Bahar, J. Haniff, A. Mamid, M. Bujang, and M. Mahmood (2014). "Pattern of Suicides in 2009: Data from the National Suicide Registry Malaysia," Asia-Pacific Psychiatry 6: 217-225.

Beattie, D., and P. Devitt (2015). Suicide: A Modern Obsession. Dublin: Liberties Press. 
Dorpat, T., and H. Ripley (1960). "A Study of Suicide in the Seattle Area," Comprehensive Psychiatry 1: 349-359.

Durkheim, E. (1951). Suicide: A Study in Sociology. New York: Routledge Classics.

Fitzpatrick, S., and I. Kerridge (2013). "Challenges to a More Open Discussion of Suicide," Medical Journal of Australia 198: 470-471.

Insel, T. (2013). Toward a New Understanding of Mental Illness. Filmed January at TEDxCaltech. www.ted.com/talks/thomas_insel_toward_a_new_understanding_ of_mental_illness (Accessed 1 June 2015).

Harrington, J., P. Boski, and M. Gelfand (2015). "Culture and National Well-being: Should Societies Emphasize Freedom or Constraint?" PLOS ONE 10: e0127173.

Hjelmeland, H., G. Dieserud, K. Dyregrov, B. Knizek, and A. Leenaars (2012). "Psychological Autopsy Studies as Diagnostic Tools: Are They Methodologically Flawed?" Death Studies 36: 605-626.

Merriam-Webster. An Encyclopaedia company. "World-weary." http://www.merriamwebster.com/dictionary/world-weary (Accessed 2 June 2015).

Pridmore, S. (2015). "Mental Disorder and Suicide: A Faulty Connection," Australian and New Zealand Journal of Psychiatry 49: 18-20.

Pridmore, S. (2009). "Predicament Suicide: Concept and Evidence," Australasian Psychiatry 17: 112-116.

Pridmore, S., and M. McArthur (2010). “An Observer's Typology of Suicide," Australasian Psychiatry 18: 112-116.

World Health Organization (2014). Preventing Suicide: A Global Imperative. Geneva: WHO. 